\title{
Immunogenicity Specimen Assessments Completion Status
}

National Cancer Institute

\section{Source}

National Cancer Institute. Immunogenicity Specimen Assessments Completion Status. NCI Thesaurus. Code C117564.

A term used to describe the state or condition of the completeness of the immunog enicity specimen assessment data. 